\title{
TOWARDS REDEFINING SOCRATIC IRONY
}

\section{Warren (Stellenbosch University)}

The nature and function of Socratic irony has been much disputed in contemporary scholarship, and there is no source which offers a satisfactory account of Socratic irony. In this article I firstly argue that Socrates' disavowals of knowledge cannot be taken literally. I then argue that Socrates also has some physical habits, in particular an attitude of superiority and the appropriation of Spartan dress, which can be interpreted as ironic within their historical context, in other words that Socrates' physical actions also suggest irony. In conclusion I argue that Socratic irony has interlinked political and pedagogic functions, and I offer suggestions for the redefinition of the concept of Socratic irony which allows for these insights.

Socrates has left behind a legacy that has continued to fascinate scholars to the present day. A large part of this fascination is because of the enigma surrounding this literary-historical character ${ }^{1}$, and which finds its embodiment in the Socratic Problem, the Socratic Method and Socratic irony. The latter has experienced a revival in the work of Gregory Vlastos, whose book Socrates: Ironist and moral philosopher (1991) raised several questions on the nature and function of Socratic irony. Vlastos himself tried to redefine Socratic irony as a complex phenomenon in which Socrates both does and does not mean what he says. This 'complex irony' (Vlastos 1991:43) varies slightly from simple irony, but is not sufficient to explain all the instances of irony ascribed to Socrates, and as such is simply not complex enough. Other attempts to redefine Socratic irony and account for this complexity have also fallen short (Vasiliou 1999; Vasiliou 2002; Wolfsdorf 2007) and has been met with criticism, most notably by Melissa Lane (2006; 2011). Furthermore, an overview of several dictionaries and encyclopaedias leaves us no more enlightened on the matter. Der neue Pauly, The Oxford encyclopaedia of ancient Greece and Rome and the Oxford Classical Dictionary do not contain entries for Socratic irony, and the entry in The Cambridge Dictionary of Philosophy (Socratic irony is 'a form of indirect communication' used by Socrates 'to praise insincerely the abilities of his interlocutors while revealing their ignorance'; Prior 1999:861) takes an oversimplified view of the concept, which is rather surprising considering the amount of philosophical scholarship done on

The question of the historicity of Socrates is still a much-disputed problem, and as such I prefer in this case to treat Socrates as a literary character based to an unknown extent on an historical person. This treatment then deals with Socrates as he is popularly perceived to be. For elaboration on this point see also note 6 . 
the topic since the $18^{\text {th }}$ century. ${ }^{2}$ Furthermore, the Historisches Wörterbuch der Rhetorik gives a fairly extensive overview of the scholarship on Socratic irony, focusing especially on ancient sources, but takes no positive steps towards defining Socratic irony, opting instead to take an objective stance. In view of this oversight, this paper will attempt to make suggestions for the reconsideration and redefinition of Socratic irony to allow for its complexities. To the discussion of Socratic irony it will add one aspect of irony that is often overlooked: figural irony. ${ }^{3}$

\section{Socrates as ironist in the ancient world}

The identification of Socrates as an ironist is almost as old as Socrates himself, and the notion of figural irony ${ }^{4}$ is by no means a new one, but one which has received regrettably little attention in scholarship over the past couple of centuries. Figural irony first appears as a coherent concept in the work of Quintilian, who identified two types of irony: irony as a trope and irony as a figure. As a trope, irony is meant to ridicule. It is the simpler of the two types, in which the meaning and the words

2 Consider for example the work of Schlegel (Albert 1993), Hegel (Nehamas 1998; Most 2007), Kierkegaard 1841; Watts 2010, Nietzsche (Kaufmann 1948; Conway 1988), Bakhtin (Zappen 1996), Lefebvre (Gardiner 2012), and Derrida 1995 on Socratic irony.

3 The simple conception of irony as a verbal phenomenon, as saying something other than is meant, was modelled on the definition of Quintilian (contrarium ei quod dicitur intelligendum est; Inst. 9.2.44), who in turn modelled his definition on the work of Cicero (De Or. 2.269-270). This view of irony pervaded until the late $18^{\text {th }}$ century. At this time the work of philosophers like Friedrich Schlegel made great strides in identifying the many complexities of irony (Nehamas 1998:65; Albert 1993:830-834; Barth 2007:1144-1145). Two additions to the theory of irony are particularly relevant to this article. The first is the notion that irony carries with it an inherent attitude of superiority and detachment (Colebrook 2004:18-19). The second is that irony is not only a verbal phenomenon, but can also be physical, a way of life (Wolfsdorf 2007:176). This form of irony was identified by Thirlwall in the late $19^{\text {th }}$ century (Hutchens 1960:356) and is a purposeful act of pretence which presents an incongruity between the attitude or appearance of the ironist and his true (dis)position. Vlastos, Vasiliou and Wolfsdorf do not take this physical aspect into account. Edmunds, however, does take note of it, but does not elaborate on its function (2004).

4 See note 3 for a further discussion of what is meant by 'figural irony'. The most notable difference between figural and verbal irony is that figural irony takes place over an extended period of time and as such becomes a way of life rather than just a singular verbal utterance from the ironist. In this respect Rorty also discusses irony as a method of criticising final vocabularies (a final vocabulary is the vocabulary which is available to a person or a culture in order to justify their actions, beliefs and lives). Final vocabularies are an extension of the ironist's person, and can only be criticised by other vocabularies, thus making irony of this sort necessarily extended and a way of life (1989:73-80; see also p.12 and note 15). 
used to convey the meaning are incompatible. In this case the meaning (that which is unsaid) is often revealed by the context in which the words were uttered (Inst. 8.6.54-55; trans. Russell 2001). As a figure, irony is an extended version of the trope. It is not meant to be understood as easily as the trope, and the meaning is more covert, yet still the opposite of what is said (or what is presented) is to be understood (Inst. 9.2.45). Quintilian connected the entire life of Socrates especially with irony as a figure (Inst. 9.2.46).

Even before Quintilian, Aristotle referred to Socrates' ironic behaviour and struggled to reconcile it with the mean between the two extremes of $\dot{\alpha} \lambda \alpha \zeta \dot{\omega} v \varepsilon i ́ \alpha$

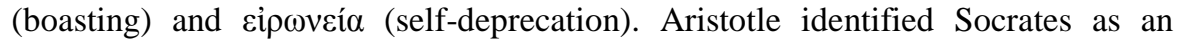
Eip $\omega v$, but argued that self-deprecation is closer to the mean (truthfulness) than boasting ( $N E$ 4.7; trans. Ross 2009). Aristotle mentions that Socrates was a habitual self-deprecator, and he says that those who dress like Spartans, which includes wearing a single threadbare cloak and being barefoot, which is here, like elsewhere, explicitly connected with Socrates, are ostentatious in their understatement ( $N E$ 4.7). Cicero (who coined the Latin ironia) ${ }^{5}$ also connected Socrates with irony (De Or. 2.269-271; trans. Sutton 1959). According to Cicero irony is humorous and witty, but it can also be austere (De Or. 2.271-274).

Connecting Socrates with irony is therefore not a great leap for the modern reader, but there are several problems that arise when attempting to formulate not only a coherent, but also a comprehensive conception of Socratic irony.

\section{Historical background and the politics of Socrates}

Socratic irony can by no means be separated from the historical context in which it developed. Trying to understand the motives of Socrates without trying to understand what sparked them will leave the reader with an insufficient idea of the meaning of Socratic irony. Furthermore, without this historical contextualisation ${ }^{6}$

5 De Or. 2.269-270; trans. Sutton 1959. It is from this Latin term that we derived our term

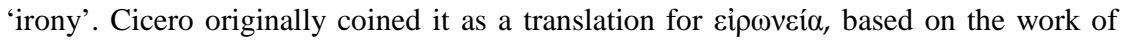
Aristotle in the Nicomachean Ethics (Vlastos 1991:23).

6 A note on the sources might be helpful here. The Socratic problem has not yet been solved, and in all probability it will never be solved — we simply do not have enough information. To highlight the complexity of this problem I offer the following: according to one school the historical Socrates is the Socrates of Plato's early dialogues. Unfortunately dating the dialogues is nearly impossible due to insufficient evidence and as such the lists of early dialogues differ. Consider the accounts of Rogers 1933:53-54, Vlastos 1985:1n1, Rowe 2007:54 and Wolfsdorf 2007:186n11. Thus even within this school there is a lack of consensus regarding the sources for the historical Socrates. This makes the choice of sources a particularly difficult one, as the inclusion or omission of one or the other may elicit stark criticism. It is my opinion, however, that limiting the 
it might not be immediately clear why some of the habits and characteristics of Socrates that are described in this paper were ironic. It only becomes apparent when we take into account the historical circumstances in which they functioned, of which I will here briefly remind the reader.

Firstly, Socrates' lifetime was not a time of peace. The Greeks were fighting the Persians for large parts of the $5^{\text {th }}$ century (Prior 2006:29; Pomeroy et al 2008: 220) and had formed the Delian League under Athenian leadership (Hornblower 2002:11-15). Athens partially funded its political change from oligarchy to democracy with money acquired from the Delian League and eventually moved the League's treasury from Delos to Athens, a controversial move. During its rule as a democratic empire Athens also supported several oligarchic city-states, presumably to keep them weak, and this was seen by some as hypocritical. Furthermore, the new democracy was not very popular with the aristocrats of Athens, and towards the end of the century there were two political coups that replaced the Athenian democracy first with the Four Hundred oligarchs and then with the violent rule of the Thirty Tyrants (Ostwald 1986:466-499). The Five Thousand, the pseudodemocratic government that ruled in the interval, made many controversial decisions of their own (Hornblower 2002:174-180).

Secondly, from the little we do know about the historical Socrates we can reasonably argue that he was born into an aristocratic family, which gave him the opportunity to serve as a hoplite in the Peloponnesian War (Wood \& Wood 1978:83). It is thus very possible that his appearance of poverty, as discussed below, was self-inflicted.

Furthermore, it is necessary to take into account what we know about Socrates' own views on politics. It has been argued that Socrates was pro-oligarchy and that his trial was in fact political, motivated by his association with some members of the Thirty Tyrants (most notably Critias). ${ }^{7} \mathrm{~T}$ H Irwin however rejects these claims on the basis that much of the textual evidence cited may represent the popular opinion 50 years after the trial of Socrates, but does not necessarily

study of Socratic irony to those sources considered to refer to the historical Socrates would be detrimental to our full understanding of Socratic irony as it is perceived today, especially in the more popular context. In this article I therefore follow the example of Edmunds 2004 in considering as primary sources the works not only of Plato, but also of Xenophon, Aristophanes, Ameipsias and Callias (of which fragments survive in Diogenes Laertius), as well as those of Aristotle, because there is no contradiction in the evidence applicable here. Where two or more sources agree on a particular trait of Socrates, that trait is thus assumed to be generally characteristic of Socrates as literaryhistorical character. Nevertheless, the dialogues of Plato are taken as the basis of the study, and other sources are taken as corroboration.

7 See for example Vlastos 1983 and Stone 1989. On Socrates' association with Critias, see Xenophon, Mem. 1.2.18, 3.14. 
represent a reliable account of the true motives of Socrates' accusers (1989:186). He then goes on to make a convincing argument that Socrates was critical of Athenian democracy (cf. Prot. 319b-d, Apol. 31d-32a), but not against it (Irwin 1989:196). Among these criticisms count Socrates' refusal to sentence the Arginusae generals to death, because it was illegal (Apol. 32b; trans. Fowler 1960) and his reference to oligarchic cities such as Sparta as well-governed (Crito 52e; trans. Fowler 1960), while refusing to leave Athens even for a day — an indication that he nonetheless preferred its laws (Irwin 1989:196; Vlastos 1983:502). With the inclusion of late Socratic dialogues such as the Republic and the Gorgias, Irwin concedes that it may appear that Socrates was anti-democratic (1989:198), but argues that it need not mean that he was pro-oligarchy. Instead, he argues that Socrates was intensely critical of the Athenian democracy, but did not suggest that there was a better practical alternative (1989:199).

The historical context in which Socratic irony was developed and in which it functioned and Socrates' views on politics are particularly relevant to the figural irony discussed below. Figural irony is however not the only component of Socratic irony, and in order to formulate a comprehensive definition of the concept, instances of verbal irony must also be discussed.

\section{Verbal irony}

For the verbal component of Socratic irony we turn to instances of verbal irony found in the dialogues of Plato. At Republic 332c-d (trans. Shorey 1943) there are indications that Socrates has taken a didactic approach to his conversation with Polemarchus, who is young and confident of his knowledge of justice. Socrates exclaims in exasperation when Polemarchus fails to understand what is expected of him, and when he gives the answer that Socrates is after, Socrates replies with 'good' in the same way a teacher would reply to a student who has given the correct answer. Socrates thus seems to have assumed the role of the teacher in this situation, and thus must see himself as having some knowledge or insight which Polemarchus does not. When Thrasymachus grows weary of Socrates' constant questioning and interrupts the conversation to accuse Socrates of being deceitful, Socrates uses irony to draw him into the conversation by telling him that he is wise, and then immediately (though indirectly) telling him exactly why he is not wise (Rep. 337b). Thrasymachus believes that Socrates has some form of knowledge, but does not see that Socrates is deliberately keeping this from Polemarchus in order to bring him to a realisation of his own. When Thrasymachus thus accuses Socrates of lying, his words are also unintentionally ironic, because Socrates is not lying, he is teaching through elenchus. 
This is not the only instance in which irony and deceit are closely linked. Two cases that are quite similar appear in Euthyphro and Gorgias. In the former, Euthyphro tells Socrates that he must go, to which Socrates replies:

You go away and leave me cast down from the high hope I had that I should learn from you what is holy, and what is not ...

(Euth. 15e; trans. Fowler 1960)

At 15b-c, however, Socrates said:

... your words do not remain fixed but walk about, and you will accuse me of being the Daedalus who makes them walk, when you are yourself much more skilful than Daedalus and make them go round in a circle? Or do you not see that our definition has come round to the point from which it started?

Socrates is thus accusing Euthyphro of changing his opinion too easily. He accuses Callicles of the same in Gorgias 481d (trans. Lamb 1946). He says that he and Callicles are the same, because they both love two things. Socrates loves Alcibiades and philosophy, Callicles loves the Athenian demos and Demos, the son of Pyrilampes. According to Socrates the difference between him and Callicles is that Socrates is a slave to philosophy, whose views 'always holds the same' (482a), whereas Callicles will always agree with his two loves, which implies that he easily changes his opinion to match that of (the) Demos. It seems that Socrates is saying that Callicles will agree with anyone, and thus that he will always be in danger of contradicting himself. When Socrates thus says that he is lucky to converse with Callicles, because if they agree on a matter it must surely be the truth (482b), he cannot mean this seriously; they may agree one minute and disagree on the exact same matter the next. It is therefore not unreasonable to say that Socrates is being ironic when he says that he could learn from either Euthyphro or Callicles.

Our last example of irony deals with Socrates' knowledge disavowal, ${ }^{8}$ one of his most famous characteristics, and comes from Plato's Apology: the story of the Delphic oracle declaring that Socrates is the wisest man (21a; trans. Fowler 1960). Socrates claims that he wished to know what the Oracle had meant by this and started questioning those who are reputed to be wise. He found that they only seemed wise, but that in truth they were not wise at all (21b-c). He concluded that he was in fact wiser than all of them, because he knew that he was not wise (21d-22e). We cannot believe him, however, when he says that he has no

I will here only give one example of Socrates' knowledge disavowal, which is dealt with extensively in the work of Vlastos 1985, Matthews 2006, Lane 2011 and Wolfsdorf 2004, amongst others. 
knowledge. In the first place, saying that he knows nothing is already a wellknown paradox, because if he doesn't know anything, how could he possibly know that he does not know? This is not the only instance in which Socrates in a sense affirms his (however incomplete) knowledge. In Apology 29b he says:

But I do know [my emphasis] that it is evil and disgraceful to do wrong and to disobey him who is better than I, whether he be god or man.

There are other cases where Socrates asserts some form of knowledge as well, such as the case in Republic 330d, in which Cephalus tells Socrates that he is right, and Socrates replies 'I assuredly am'. Socrates' claim that he does not know thus means something other than its literal meaning, though it does not necessarily mean the opposite. His disavowals of knowledge can thus be taken to be ironic.

However, verbal irony is not the only aspect of Socratic irony, there is a physical aspect as well. As has already been mentioned, this physical aspect was noticed as early as the $1^{\text {st }}$ century AD in the work of Quintilian, who was at the time expanding on the work of Aristotle (Nicomachean Ethics 4.7) and Cicero (De Oratore). According to Quintilian Socratic irony was a way of life rather than a rhetorical device, and its aim was to remain concealed. As a long-term irony it sought to lay bare some sort of contradiction or incongruity and it often poked fun at serious matters (such as the pretended wisdom of others) in order to draw attention to them (Inst. 9.2.51-53).

\section{Figural irony}

Socratic figural irony finds its expression in two distinctive characteristics, both well attested to in our sources. The first is the attitude of superiority, ${ }^{9}$ the second is Socrates' Spartan dress, and the two are often mentioned in close connection. These two characteristics of Socrates were well known in Athens, and we find the earliest reference to it in Aristophanes' Clouds:

... you [Socrates], because you strut like a popinjay through the streets and cast your eyes sideways and, unshod, endure many woes and wear a haughty expression for our sake [my emphasis]

(Clouds 362-363; trans. Henderson 1998).

The verb $\beta \rho \varepsilon v \theta v i \varepsilon$ here initially presents some difficulties. The etymology of the word is uncertain, but it has been convincingly argued that it comes from $\beta \rho \varepsilon ́ v \theta o \varsigma$,

An attitude of superiority has more recently been recognised as being a trait that is often associated with the ironist (Colebrook 2004:18-19). 
the water bird, known for walking with its chest out (Edmunds 2004:195). ${ }^{10}$ $\beta \rho \varepsilon ́ v \theta o \varsigma$ also means 'proud', and the LSJ defines $\beta \rho \varepsilon v \theta v ́ o \mu \alpha 1$ as 'to bear oneself haughtily, hold one's head high' or 'swagger'. These words clearly carry a connotation of superiority which is supported by the act of casting the eyes sideways ( $\tau \dot{\omega} \varphi \theta \alpha \lambda \mu \grave{\omega} \pi \alpha \rho \alpha \beta \alpha \dot{\lambda} \lambda \lambda \varepsilon 1 \zeta)$ and wearing a haughty expression $(\sigma \varepsilon \mu \nu о \pi \rho \circ \sigma \omega \pi \varepsilon i \bar{\zeta})$. Moreover, Aristophanes says that Socrates does these things for the sake of others, but the words 'for our sake' could easily be missed if the audience is not paying enough attention or if the words are not emphasised. Did he perhaps see something through Socrates' ironic attitude which led him to believe that Socrates had good reasons to act as he did? I believe so. ${ }^{11}$

We see further elaboration on what it means to 'endure many woes' in lines 412-417, which describe the lengths someone has to go to in order to prove themselves a follower of Socrates:

$\ldots$ if you're retentive and a cogitator, if endurance abides in your soul, if you don't tire out either standing or walking, if you're not too annoyed by the cold or too keen on having breakfast, if you stay away from wine and gymnasiums and all other follies ...

(Clouds 412-417)

Socrates makes a habit of denying himself whatever he does not absolutely need, and is thus known for wearing the same cloak year-round, consuming poor quality food and drink and his extreme endurance. These characteristics were doubtlessly things that the audience would have recognised as typically Socratic. The same characteristics, as well as Socrates' attitude of superiority, are mentioned by Ameipsias in the Konnos and Callias in the Captives, of which only fragments survive. The following excerpts are found in The lives of eminent philosophers by Diogenes Laertius (trans. Hicks 1925):

Socrates ... You are a robust fellow. Where can we get you a proper cloak?

Your sorry plight is an insult to the cobblers.

And yet, hungry as he is, this man has never stooped to flatter.

(Konnos; Lives 2.27-28)

A: Pray why so solemn, why this lofty air?

B: I've every right; I'm helped by Socrates.

(Captives; Lives 2.18)

10 See also Frisk 1960:266 and LSJ, both of which make the connection.
11 On this point see also Petrie 1911:519. 
The obvious criticism against my use of these sources is that they are comedies, written for humorous effect, and thus not an accurate reflection of the reality. However, it must be noted that a parody cannot work if there is no recognition of the person being parodied in it. Hegel argued this point, stating that the Clouds therefore must be an exaggerated account of the historical Socrates (Most 2007:13). Even so, there is also mention of Socrates' swagger and his austerity in the more traditional sources. In Plato's Apology, Socrates mentions the latter himself:

... I [n]ever exacted or asked pay of anyone. For I think I have a sufficient witness that I speak the truth, namely, my poverty.

(Apology 31c; trans. Fowler 1960)

It's also mentioned by Phaedrus in Plato's Phaedrus:

Phaedrus: I am fortunate, it seems, in being barefoot, you are so always

(229a; trans. Lamb 1946).

Alcibiades quotes Clouds 412-417 in Plato's Symposium (221b), using $\beta \rho \varepsilon v \theta v o ́ \mu \varepsilon v o \varsigma$ to describe Socrates's gait, and Antiphon in Xenophon's Memorabilia says that Socrates lives 'a life that would drive even a slave to desert his master' (1.6.2-3; trans. Marchant 1968), including consuming poor quality food and drink, wearing a single worn cloak year round and not wearing any shoes or a tunic (1.6.3). Socrates lived a life of poverty, but we have already seen that he was born into a rank which allowed him to fight as a hoplite in the war, and thus he could not have been as poor as he is so often described to have been. His appearance of poverty must then have been by choice.

Socrates' attitude of superiority is again mentioned in Plato's Symposium (220b), when Alcibiades says of his shoelessness and single cloak:

The soldiers looked askance at him, thinking that he despised them.

and in Xenophon's Symposium, when Callias asks him what he is proud of:

Socrates drew up his face into a very solemn expression and answered, 'The trade of a procurer' (3.10).

In this passage the verb $\dot{\alpha} v \alpha \sigma \pi \alpha \dot{\alpha} \alpha \varsigma$ ( $\dot{\alpha} v \alpha \sigma \pi \alpha \dot{\alpha} \omega)$, meaning 'to draw up', gives the impression of an important air, and $\sigma \varepsilon \mu \nu \tilde{\omega} \zeta$, translated here as 'solemn', can also be translated negatively as 'haughty' or 'pompous' ( $c f$. $\sigma \varepsilon \mu \nu$ o $\rho \rho \sigma \sigma \omega \varepsilon i \tilde{\varsigma}$ at Clouds 363; LSJ). Alcibiades also mentions Socrates casting a calm, slow glance at 


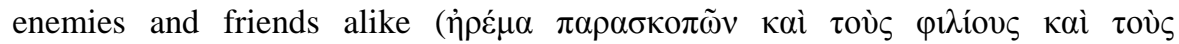
$\pi \mathrm{o} \lambda \varepsilon \mu$ íous; Symp. 221b), which has been interpreted as conveying an attitude of ridicule and depreciation (Edmunds 2004:195). The attitude of superiority that Socrates affects is clear, but it is not immediately clear why this attitude along with his Spartan dress may be interpreted as ironic. This physical manifestation of irony is elusive and, as Quintilian said, aims to remain concealed. In order to fully understand it we must take the function of Socratic irony in its verbal form and the historical circumstance within which it developed into account.

\section{The function of Socratic irony}

The main components of Socrates' verbal irony are self-deprecation (as in the case of Euthyphro and Callicles) and knowledge disavowal (Apol. 21d). In many cases his self-deprecation is in itself a form of knowledge disavowal, but we have seen that Socrates did at times admit to having some form of knowledge. We thus have to ask why he claims he has none. The current prevalent notion of the function of Socratic irony is that it is didactic (Lane 2011:243). This in itself is not enough, however. We must ask what Socrates means to teach ${ }^{12}$ and how irony is meant to help him do so. As for the former, Socrates means to discover the content of virtue. His method is to engage any person willing to converse with him on this matter, and irony can be a way of keeping an interlocutor in the conversation. It works in two ways. In the first Socrates is ironic and means to be perceived as such, as in the case of Callicles in the Gorgias. The interlocutor is wounded by Socrates' irony and wants to prove his point, thus continuing the conversation (Lane 2011:252). In the second case Socrates means for his irony to remain concealed, meaning he is belittling himself and ironically praising his opponent, which gives the opponent confidence to engage in the conversation (Lane 2011:252).

Socrates thus both gives off an air of superiority when he puts his opponents down, asserting that he is leading the argument, and reinforces the possibility of superiority of his opponents, thereby encouraging them to engage in elenchic discussion and further assert their domination of the argument. Socrates decides which of the two tactics is appropriate for each new interlocutor. Continuing the conversation gives both Socrates and his opponents a better chance at discovering the nature of virtue.

The pedagogic function may also be present in non-verbal aspects of Socratic irony, such as an attitude of superiority and Spartan dress. Within the

12 'Teach' may not be the most apt word in this case, because when Socrates teaches, he himself is also a student. We cannot take his avowals of knowledge as indicative of certain knowledge, and thus both he himself and his interlocutor must 'discover' through elenchic enquiry. 
historical background discussed earlier Socrates' critical pro-democratic stance and association with known oligarchs becomes problematic. Why would he associate with men so obviously against his philosophical goal, men who do not seek the nature of virtue as Socrates does? Furthermore, these known oligarchs, the aristocrats of Athens, adopted a distinctively Spartan style in the 5th century BC. They imitated many things that the Spartans were known to do as an outward expression of their oligarchic sympathies. This included wearing the short cloak that Socrates was so often ridiculed for (De Brohun 2001:19). Why would he go so far as to dress like them?

It may be argued that aspects that have here been identified as figural irony,

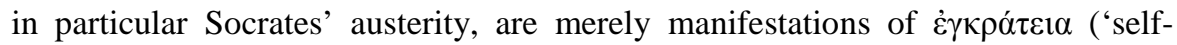
mastery' or 'self-control') and not ironic at all, but this answer remains unsatisfactory. It does not do to explain Socrates' attitude of superiority, nor does it

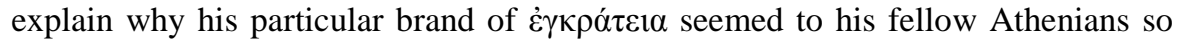
intensely Spartan. ${ }^{13}$ For this there seems to be only two reasonable answers: either Socrates is a Laconophile and oligarchic sympathiser, or he is being ironic. Since it cannot be - has not yet been - convincingly argued that the former is the case, perhaps the latter merits some investigation.

If we concede to Irwin that Socrates may have been intensely critical of the Athenian democracy while still preferring it over other existing forms of government, and if we accept the argument that Socrates is not a Laconophile, the following problem presents itself: Socrates stands very near the beginning of a long

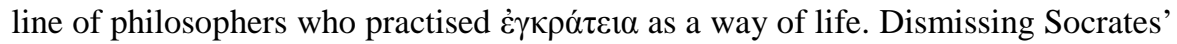
austere dress and poverty as merely reflecting ironic commentary on his environment delegitimizes an entire tradition, built on fairly solid philosophical

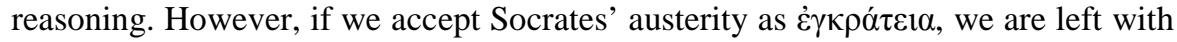
the nagging question of why his single threadbare cloak would be specifically Spartan, especially if he loved Athens as much as he is said to have done. ${ }^{14}$ It would seem to be something he would have had to go out of his way to find, and why go to all that trouble? Taking into account the fact that Socrates was wellknown to have been friends with known oligarchs, including at least one of the Thirty Tyrants, perhaps it's not so ridiculous to say that Socrates dressed to be part of the group.

13 Socrates' short cloak is twice in Plato described as a $\tau \rho$ í $\beta \omega v$ (Symp. 219b; Prot. 335d), which is specifically brought into connection with Spartan dress, $c f$. Demosth. 54.34:

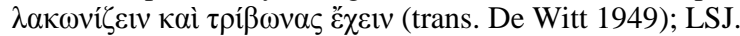

$14 C f$. Vlastos 1983:498, who argues that the Socrates of the Crito loved Athens so much that he refused to leave the city even if only for a day, and therefore clearly preferred its laws over those of Sparta. 
According to Rorty ironists strive to criticise vocabularies that are considered final, ${ }^{15}$ because they constantly doubt the validity of their own final vocabularies (1989:73). The only way for the ironist to criticise final vocabularies is with another vocabulary of its kind, thus a culture can only be criticised with / by another culture, a person by another person, etc. (Rorty 1989:80). What this means is that the ironist has to constantly extend his own vocabulary by submerging himself in another vocabulary in order to criticise at all, and this is more than just a verbal phenomenon. It is a physical way of being.

It is therefore possible that Socrates' physical manifestation of irony was aimed at his anti-democratic associates. Dressing like the aristocrats he interacted with on a regular basis would have allowed him access to their circle and the chance to converse with them, he would have been submerging himself in their vocabulary while simultaneously questioning the validity of his own vocabulary. Many of his interlocutors in Plato are pro-Spartan, and yet he did not agree with them as one would expect him to do if he really was one of them. Instead he argued fervently against them. By dressing like a Spartan Socrates would have gained access to the ranks of the educated elite. As an insider and a friend, Socrates would have been able to use that access to openly criticise them.

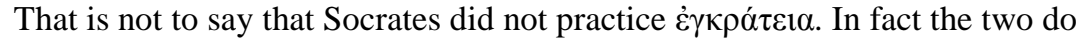
not at all seem mutually exclusive, but rather Socratic irony seems to become an extension of the former in service of Socrates' philosophical goals. In the same way his swagger too may have been an ironic appropriation of the Laconic attitude he saw in his associates, and in fact an exaggeration thereof. During the reign of the Thirty they transformed Athens so that they were the city's elite while all other citizens belonged to the lower classes. These aristocrats thus also thought they were superior, and Socrates was known for the same attitude. I would argue, however, that Socrates was ironically participating in the activities of his associates in order to criticise their political views. Whether he intended for his associates to see clearly that he was mocking them in order to incite them to deeper philosophical inquiry and ultimately a deeper realisation of knowledge (specifically of virtue) to help them make better decisions, both politically and morally, is unclear. However, for Socrates to continue the search for virtue, particularly in discussion with various interlocutors (many of whom are proSpartan), it would make sense to use irony didactically.

15 A 'final vocabulary' is that vocabulary which is available to a person or a culture in order to justify their actions, beliefs and lives. Rorty argues that 'it is 'final' in the sense that if doubt is cast on the worth of these words, their user has no noncircular argumentative recourse' (1989:73). 
This brings to light another irony: Socrates' insistence that he does not take part in politics. His criticism of the Athenian democracy should already stand as an example of political involvement at some level, as should his involvement in the trial of the Arginusae generals, during which he refused to sentence them to death because it was illegal (Apol. 32b). His philosophical mission here necessitated his taking action. In Gorgias he declared himself the only true statesman:

I think I am one of few, not to say the only one, in Athens who attempts the true art of statesmanship, and the only man of the present time who manages affairs of state ...

(Gorgias 521d)

Notably also, at Gorgias 473e Socrates says to Polus: 'I am not one of your

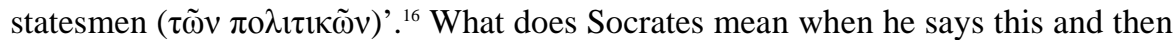
contradicts himself a few pages later? It is possible that he means he is not a statesman like the other corrupt statesmen in Athens at the time. Callicles, for example, will say whatever (the) Demos wants to hear. Instead, Socrates is what a politician should be: critical, constantly seeking the nature of virtue, law-abiding and willing to learn from others.

Can Socrates therefore literally mean that he does not take part in politics? I do not believe so. It is more likely that what Socrates means is that there should be no need to take part in the kind of politics prevalent in Athens in the 5th century $\mathrm{BC}$ in the first place. An ironic attitude, which by its very nature confines some of its onlookers to being 'outsiders' (i.e. those who don't 'get' the irony; $c f$. Muecke 1969:34), would have offered Socrates a way to display publically his disapproval of the state of Athenian politics in the 5th century without offending the ruling class.

Taking into account what has been said about the nature and function of Socratic irony, it becomes clear that a redefinition of Socratic irony which allows for its many complexities is necessary. The following aspects need to be taken into account:

1) Socratic irony is a deliberate act of pretence through which an ironist attempts to gain access to a political / social group;

2) it is a philosophical and political mode of being;

3 ) it typically finds its expression in self-deprecation, disavowals of knowledge and a physical attitude of austerity and superiority;

16 My emphasis. 
4) its purpose is to lead its targets to a deeper independent search for knowledge and to criticise the status quo, particularly in a political sense.

There may be further aspects to Socratic irony, to which end further study is needed. In particular it is also suggested that the possibility of the success of Socratic irony as a pedagogic and political tool needs to be examined.

Kierkegaard said that Socrates had only irony as 'infinite, absolute negativity' (1966:287) to offer, and nothing more, but Hegel, who originally held the same view and from whom Kierkegaard borrowed the phrase, came to see something more, and near the end of his life argued that Socrates did have some positive knowledge to impart (Most 2007:14). Were Socrates successful, his associates would have realised that they were the targets of Socratic irony. This would have lead them to reflect on what had brought them to that point. But, as Nietzsche observed, Socrates was not taken seriously in Athens and thus failed in his political mission (Conway 1980:260-262). Is failure a necessary outcome of Socratic irony? That still remains an open question.

\section{BIBLIOGRAPHY}

Albert, G 1993. Understanding Irony: Three Essais on Friedrich Schlegel. MLN 108.5:825-848.

Barth, A 2007. Irony. In Landfester, M, Cancik, H \& Schneider, H (eds.), Brill's New Pauly. Classical Tradition Vol. 2. Leiden: Brill. 1144-1145.

Behler, E 1998. Ironie. In Ueding, G (ed.), Historisches Wörterbuch der Rhetorik. Band 4. Tübingen: Max Niemeyer Verlag.

Colebrook, C 2004. Irony: The new critical idiom. London: Routledge.

Conway, D W 1988. Solving the problem of Socrates: Nietzsche's Zarathustra as political irony. Political Theory 16.2:257-280.

De Brohun, J 2001. Power dressing in ancient Greece and Rome. History Today 51.2:18-26.

Derrida, J 1995. The gift of death (trans. D Wills). Chicago: The University of Chicago Press.

De Witt, N W 1949. Demosthenes. Loeb Classical Library 374. London: William Heinemann Ltd.

Edmunds, L 2004. The practical irony of the historical Socrates. Phoenix 58.3/4:193-207.

Fowler, H N 1960. Plato: Euthyphro, Apology, Crito, Phaedo, Phaedrus. Vol. 1. Loeb Classical Library 36. London: William Heinemann Ltd.

Frisk, H 1960. Griechisches etymologisches Wörterbuch. Band 1: A-Ko. Heidelberg: Carl Winter. 
Gagarin, M \& Fantham, E (eds.) 2010. The Oxford encyclopedia of ancient Greece and Rome. Vol. 6. Oxford: Oxford University Press.

Gardiner, M E 2012. Post-romantic irony in Bakhtin and Lefebvre. History of the Human Sciences 25.3:51-69.

Guthrie, W K C 1969. A history of Greek philosophy. Vol. 3. Cambridge: Cambridge University Press.

Henderson, J (trans.) 1998. Aristophanes: Clouds, Wasps, Peace. London: Harvard University Press.

Hicks, R D (trans.) 1925. Diogenes Laertius: The lives of eminent philosophers. Vol. 1. Loeb Classical Library 185. London: William Heinemann.

Hornblower, S 2002. The Greek world: 479-323 BC ( $3^{\text {rd }}$ edition). London: Routledge.

Hutchens, E N 1960. The identification of irony. ELH 27.4:352-363.

Irwin, T H 1989. Socrates and Athenian democracy. Review of 'The trial of Socrates' by I F Stone. Philosophy and Public Affairs 18.2:184-205.

Kaufmann, W A 1948. Nietzsche's admiration for Socrates. Journal of the History of Ideas 9.4:472-491.

Kierkegaard, S 1841. On the concept of irony with constant reference to Socrates (trans. Lee M. Capel). 1966. London: Collins.

Lamb, W R M (trans.) 1946. Plato: Lysis, Symposium, Gorgias. Vol. 5. Loeb Classical Library 166. London: William Heinemann Ltd.

Landfester, M, Cancik, H \& Schneider, H (eds.) 2007. Brill's New Pauly. Leiden: Brill.

Lane, M 2006. Evolution of Eirōneia in Classical Greek Texts: Why Socratic Eirōneia is not Socratic irony. In Sedley, D (ed.), Oxford Studies in Ancient Philosophy. Vol. XXXI. Oxford: Oxford University Press, 49-83.

Lane, M 2011. Reconsidering Socratic irony. In Morrison, D R (ed.), The Cambridge companion to Socrates. New York: Cambridge University Press. 237-259.

Liddell, H G \& Scott, R 1968. A Greek-English lexicon (revised $9^{\text {th }}$ edition). Oxford: Clarendon Press.

Marchant, E C 1968. Xenophon: Memorabilia and Oeconomicus. Vol. 4. Loeb Classical Library 168. London: William Heinemann Ltd.

Matthews, G B 2006. Socratic ignorance. In Benson, H H (ed.), A companion to Plato. Blackwell Companions to Philosophy 36. Oxford: Blackwell. 103-118.

Most, G W 2007. Socrates in Hegel. In Trapp, M, Socrates in the nineteenth and twentieth centuries. Hampshire: Ashcroft Publishing Ltd. 1-17.

Muecke, D C 1969. The compass of irony. London: Methuen \& Co Ltd. 
Narcy, M \& Zinsmaier, T 2007. Sokratik. In Ueding, G (ed.), Historisches Wörterbuch der Rhetorik. Band 8. Tübingen: Max Niemeyer Verlag.

Nehamas, A 1998. The art of living: Socratic reflections from Plato to Foucault. Berkeley: University of California Press.

Ostwald, M 1986. From popular sovereignty to sovereignty of law: Law society, and politics in fifth-century Athens. Berkeley: University of California Press.

Petrie, R 1911. Aristophanes and Socrates. Mind 20.80:507-520.

Pomeroy, S et al. 2008. Ancient Greece: A political, social, and cultural history. New York: Oxford University Press.

Prior, W J 1999. Socratic irony. In Audi, R (ed.), The Cambridge Dictionary of Philosophy ( $2^{\text {nd }}$ edition). New York: Cambridge University Press. 861.

Prior, W J 2006. The Socratic problem. In Benson, H H (ed.), A companion to Plato. Blackwell Companions to Philosophy 36. Oxford: Blackwell. 25-35.

Rhodes, P J 1992. The Delian League to 449 BC. In Lewis, D M et al. (eds.), The Cambridge Ancient History ( $2^{\text {nd }}$ edition). Vol. 5. Cambridge: Cambridge University Press. 34-61.

Rogers, A K 1933. The Socratic problem. New Haven: Yale University Press.

Rorty, R 1989. Contingency, irony, and solidarity. Cambridge: Cambridge University Press.

Ross, D (trans.) 2009. Aristotle: The Nicomachean ethics. Oxford: Oxford University Press.

Rowe, M W 2007. Wittgenstein, Plato, and the historical Socrates. Philosophy $82: 45-85$.

Russell, D A (trans.) 2001. Quintilian: The orator's education, Books 6-8. Loeb Classical Library 126. London: Harvard University Press.

Russell, D A (trans.) 2001. Quintilian: The orator's education, Books 9-10. Loeb Classical Library 127. London: Harvard University Press.

Shorey, P (trans.) 1943. Plato: The republic. Vol. 1. Loeb Classical Library 237. London: William Heinemann Ltd.

Stone, I F 1989. The trial of Socrates. London: Pan-Picador.

Sutton, E W (trans.) 1959. Cicero: De oratore. Vol. 1. Loeb Classical Library 348. London: William Heinemann Ltd.

Todd, O J (trans.) 1968. Xenophon: Symposium and Apology. Vol. 4. Loeb Classical Library 168. London: William Heinemann Ltd.

Vasiliou, I 1999. Conditional irony in the Socratic dialogues. The Classical Quarterly 49.2:456-472.

Vasiliou, I 2002. Socrates' reverse irony. The Classical Quarterly 52.1:220-230.

Vlastos, G 1983. The historical Socrates and Athenian democracy. Political Theory 11.4:495-516. 
Vlastos, G 1985. Socrates' disavowal of knowledge. The Classical Quarterly 35.138:1-31.

Vlastos, G 1991. Socrates: Ironist and moral philosopher. Cambridge: Cambridge University Press.

Watts, D 2010. Subjective thinking: Kierkegaard on Hegel's Socrates. Bulletin of the Hegel Society of Great Britain 66:23-44.

Wolfsdorf, D 2004. Socrates' avowals of knowledge. Phronesis 49.2:75-142.

Wolfsdorf, D 2007. The irony of Socrates. The Journal of Aesthetics and Art Criticism 65.2:175-187.

Wood, E M \& Wood, N 1978. Class ideology and ancient political theory: Socrates, Plato, and Aristotle in social context. Oxford: Basil Blackwell.

Zappen, J P 1996. Bakhtin's Socrates. Rhetoric Review 15.1:66-83.

Zuckert, C H 1988. On the role of spiritedness in politics. In Zuckert, C H (ed.), Understanding the political spirit: Philosophical investigations from Socrates to Nietzsche. New Haven: Yale University Press. 1-29. 